\title{
Performance of Broilers and Native Chickens Fed with Unfermented and Fermented Arenga Waste
}

\author{
Aisyah Nurmi, Nurainun Harahap, and Melia Afnida Santi \\ Faculty of Animal Husbandry, Universitas Muhammadiyah Tapanuli Selatan (UM Tapsel), Indonesia
}

\begin{abstract}
The objectives of this research were to study the performances of broilers and native chicken given arenga waste (APAF) fermentation by Saccaromyces cerevisiae and arenga waste unfermentation (APA) in the ration. Sixty day-old chicks of broiler Arbor Acres strain and sixty native chicken were divided into four dietary treatments and three replications (10 birds/replicate). Design of this experiment was completely randomized design factorial $2 \times 2$, with factor $\mathrm{A}$ was feeding ( $\mathrm{A} 1=$ arenga waste unfermentation, $\mathrm{A} 2=$ arenga waste fermentation), and factor $\mathrm{B}$ was chickens type (B1=native chicken, $\mathrm{B} 2=$ broilers). The variables observed were: daily weight gain, feed consumption, and feed conversion. The results showed that the performances of the broiler given fed with unfermented and fermented arenga waste showing no significant differences between all treatments. The results showed that there is an interaction between feeding and chicken type was no significant differences $(\mathrm{P}>0.05)$. Conclusion from this research of using fermented and unfermented arenga waste until level of $2.5 \%$ in ration showed no significant differences in the performance.
\end{abstract}

Keywords: arenga, broilers, native chicken, performance

Received 18 July 2018 | Revised 03 August 2018 | Accepted 10 August 2018

\section{Introduction}

The arenga waste meal (Arenga pinnata, Merr) is a disposed materials from arenga meal industry which is available abundantly. As the other waste materials, the nutrients contents of arenga waste meal is low to which is required on enrichment. Fermentation technology is one effort to increase the content of food substances and reduce the content of anti nutrition substances. In the fermentation process the substrate used must contain the elements of carbon $(\mathrm{C})$ and nitrogen $(\mathrm{N})$ required by microorganisms for growth. Fermentation results depend on feed ingredients as substrates, kinds of microbes or inoculums, and environmental conditions that greatly affect the growth and metabolism of these microbes.

Feed is one factor very important production, however limited availability with price expensive ones often become obstacles for businesses farm. Therefore it needs to be pursued alternative feed ingredients that can be used as low-cost animal feed, does not compete with human needs, easy

*Corresponding author at: Faculty of Animal Husbandry, Universitas Muhammadiyah Tapanuli Selatan (UM Tapsel), Padangsidimpuan, 22716, Indonesia

E-mail address: aisyah.nurmi@um-tapsel.ac.id 
to get and good quality. One of alternative feed ingredients that can be used is arenga waste dregs. Availability of arenga waste is quite abundant and arrived currently still neglected to push the initiative to be used as an alternative feed. Therefore, the present study was conducted to investigate the utilization of arenga waste unfermented and fermented diets on performance of native and broilers chicken.

\section{Materials and Methods}

\subsection{Experimental Location, Source and Processing of Fermented Arenga Waste}

The study was conducted at the poultry unit of the Faculty of Animal Husbandry, South Tapanuli Muhammadiyah University, Padang Sidimpuan, North Sumatera. The material used in this research is arenga waste obtained by Bulu Mario Village Sipirok Tapanuli Selatan North Sumatera, Saccharomyces cerevisiae inoculum obtained from yeast tape.

The flow chart of the arenga waste fermentation process by S. cerevisiae is as follows:

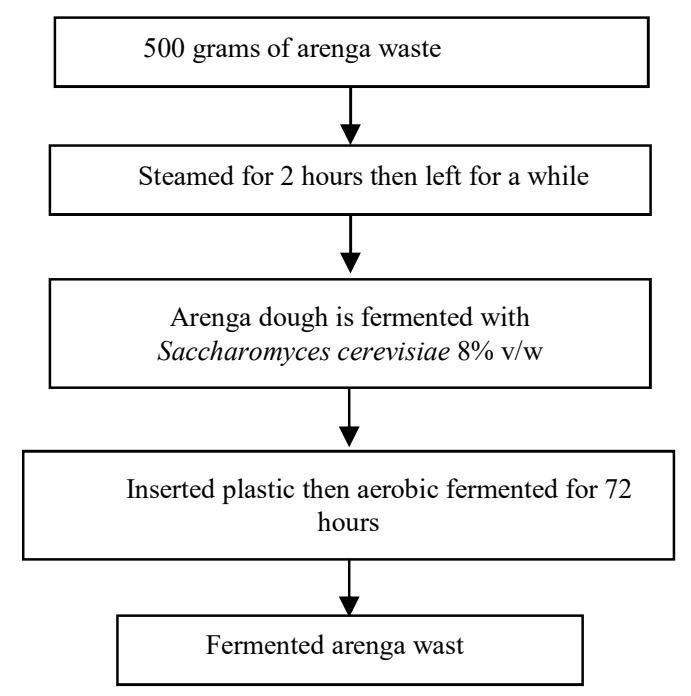

Figure 1. Flow Diagram of the Process of Making Fermented Arenga Waste [1]

Composition of the experimental diets in mash form having $20 \%$ of crude protein were formulated for the experiment (Table 1).

\subsection{Birds and Management}

The study used 120 days old chick (DOC) broiler strains produced by PT Charoen Pokphand Jaya Farm Indonesia and native chicken. The study used sixty day-old chicks of broiler Arbor Acres strain and sixty native chicken were divided into dietary treatments and three replications (10 chicken /replicate). 
Table 1. Ingredient Composition of the Experimental Diets

\begin{tabular}{lcc}
\hline \multicolumn{1}{c}{ Ingredients } & $\begin{array}{c}\text { Unfermented } \\
\text { Arenga waste (A1) }\end{array}$ & $\begin{array}{c}\text { Fermented } \\
\text { Arenga Waste (A2) }\end{array}$ \\
\hline Maize & 57.00 & 57.00 \\
Rice bran & 7.30 & 7.30 \\
Soybean meal & 24.50 & 24.50 \\
Arenga Waste & 2.50 & 2.50 \\
Fish meal & 6.70 & 6.70 \\
Palm oil & 1.00 & 1.00 \\
DCP & 0.10 & 0.10 \\
CaCo3 & 0.50 & 0.50 \\
Salt & 0.10 & 0.10 \\
Premix & 0.30 & 0.30 \\
Calculated composition & & \\
Metabolizable Energy (kkal/kg) & 2942.50 & 2943.70 \\
Crude Protein (\%) & 20.00 & 20.05 \\
Fat (\%) & 2.79 & 3.79 \\
Crude fiber (\%) & 3.90 & 3.79 \\
\hline
\end{tabular}

The chicken were weighed individually and allotted to 12 floor pens ( $1 \times 2 \mathrm{~m})$ containing 10 birds each. Each pen was equipped with a trough feeder and a bell shaped drinker. Each of the formulated mashes was fed ad libitum to chicken in four selected pens in a completely randomized design for a period of 7 week. Drinking water was also supplied ad libitum throughout the experimental period. Other equipment used are scales, curtains, brooms, thermometers, brooders (heaters), and exhaust fans.

\subsection{Experimental Design}

This research used factorial completely randomized design (CRD) $2 \times 2$ and 3 replications, with factor $\mathrm{A}$ was feeding ( $\mathrm{A} 1$ = arenga waste unfermentation, $\mathrm{A} 2$ = arenga waste fermentation), and factor $\mathrm{B}$ was chicken types $(\mathrm{B} 1=$ native chicken, $\mathrm{B} 2=$ broilers). The treatment was given as many as 4 treatments which are a combination of factor A, namely 2 types of feed (A1: $2.5 \%$ fermented arenga waste, and A2: $2.5 \%$ fermented arenga waste) and factor B, namely 2 types of chickens (B1: native chicken, B2: broilers). The details of treatment in the study are as follows: $\mathrm{A} 1 \mathrm{~B} 1=$ $2.5 \%$ fermented arenga waste, native chicken; $\mathrm{A} 1 \mathrm{~B} 2=2.5 \%$ fermented arenga waste, broiler chicken; $\mathrm{A} 2 \mathrm{~B} 1=2.5 \%$ fermented arenga waste, native chicken $\mathrm{A} 2 \mathrm{~B} 2=2.5 \%$ fermented arenga, broiler chicken.

The variables observed were: daily weight gain, feed consumption, and feed conversion ratio. The experiment was conducted for 7 weeks with the adaptation period for 2 weeks.

\section{Results and Discussion}

\subsection{Daily Weight Gain}

Body weight gain is one of the criteria that can be used to evaluate the quality of poultry rations, because the growth obtained from an experiment is one indication of the utilization of food 
substances from the feed given. The increase in body weight is the result of enlarging and increasing the weight of body tissues. Rapid growth character and have the ability to convert feed into meat in a relatively short time compared to other poultry makes broiler chickens have the privilege even though the potential can only be achieved with good management, one of which is the feed. The feed occupies the largest portion of production cost in the broiler farming business ( $70 \%$ of production cost).

Table 2. Weight Daily Gain of Broilers and Native Chickens Fed Diet Containing Fermented and Unfermented Arenga Waste (grams/day)

\section{Type of Chicken}

\begin{tabular}{lcccc}
\cline { 2 - 3 } $\begin{array}{c}\text { Factor A } \\
\text { (Arenga Waste) }\end{array}$ & $\begin{array}{c}\text { B1 } \\
\text { (Native } \\
\text { Chicken) }\end{array}$ & $\begin{array}{c}\text { B2 } \\
\text { (Broilers) }\end{array}$ & Average AB & Average A \\
\hline A1 & 5.841 & 20.144 & 12.993 & \\
(unfermented & 4.909 & 20.423 & 12.666 & \\
arenga waste) & 7.159 & 20.687 & 13.923 & $13.194^{\mathrm{ns}}$ \\
Average AB & 5.970 & 20.418 & & \\
A2 & 7.418 & 22.078 & 14.748 & \\
(Fermented & 6.719 & 20.357 & 13.538 & \\
arenga waste) & 5.963 & 20.432 & 13.198 & \\
Average AB & 6.700 & 20.956 & & \\
Average B & $6.335^{\mathrm{a}}$ & $20.687^{\mathrm{b}}$ & & $\mathrm{ns}$ \\
\hline
\end{tabular}

Note: A1B1: Arenga waste unfermentation for chicken native; A1B2: arenga waste un fermentation for broiler chicken;

A2B1: Arenga waste fermentation for native chicken; A2B2: arenga waste fermentation for broiler chicken.

${ }^{a b}$ Means within the same row with different superscripts significantly different $(\mathrm{P}<0.05)$; ns : means not significant

The average daily weight gain increase during the study at lower chickens $(6,335$ grams/day) compared with broiler chicken $(20,687 \mathrm{gram} /$ day $)$. The weight gain is influenced by the consumption of nutrient feed, and supported by the opinion which states that feed consumption has a great influence on the increase of body weight of the livestock [1]. In addition to feed consumption, it is also added that growth in general is also influenced by sex, hormonal, genetic, and environmental factors (temperature, humidity, and rainfall). From the table it can be seen quantitatively the use of arenga fermentation with Saccaromyces cereviceae showed the increase of body weight in chicken better when compared with the non arenga fermented.

There is no interaction $(\mathrm{P}>0.05)$ between factor A and B. Similarly in factor A (arenga waste unfermentation) showed nonsignificant $(\mathrm{P}>0.05)$, but factor $\mathrm{B}$ (arenga waste fermentation) shows a significant differences $(\mathrm{P}<0.05)$. From DMRT test to $\mathrm{B}$ factor, $\mathrm{B} 1$ (native chicken) was significantly different $(\mathrm{P}<0.05)$ with $\mathrm{B} 2$ treatment (broiler chicken). The results of variance analysis indicate that the use of arenga waste in ration, fermented or not give effect to the daily body weight gain of chicken. In this case the increase in body weight is better in broiler chickens, than in native chicken. 
The native chicken in this study is very low (6,700 grams/day), when compared with the results of research that giving sago poultry to domestic poultry for 8 (eight) weeks in Koya Barat village, Municipality of Jayapura [2]. In this study the highest body weight gain of 100 grams per week was below the average of previous studies (120 g/week) with an additional $20 \%$ sago [3]. The use of sago flour in the 12-week-old chicken ration resulted in a fairly high bodyweight increase compared with sago starchless rations, with a conversion rate of 3.5 grains [4]. Rations that have a high crude fiber content above $5 \%$ should be given to the mother chicken and not suitable for chicks. If the crude fiber content is above 5\% then the amylose content is high enough should be used in growth and parent rations and not suitable for chicks. Factors that affect the consumption of rations are energy levels, amino acid balance, level of ration fineness, livestock activity, weight, growth rate and ambient temperature. From the results of this study was submitted that the addition of nonfermented arenga waste and fermented up to $2.5 \%$ of the total rations provide a fairly good response to the growing power of domestic chickens.

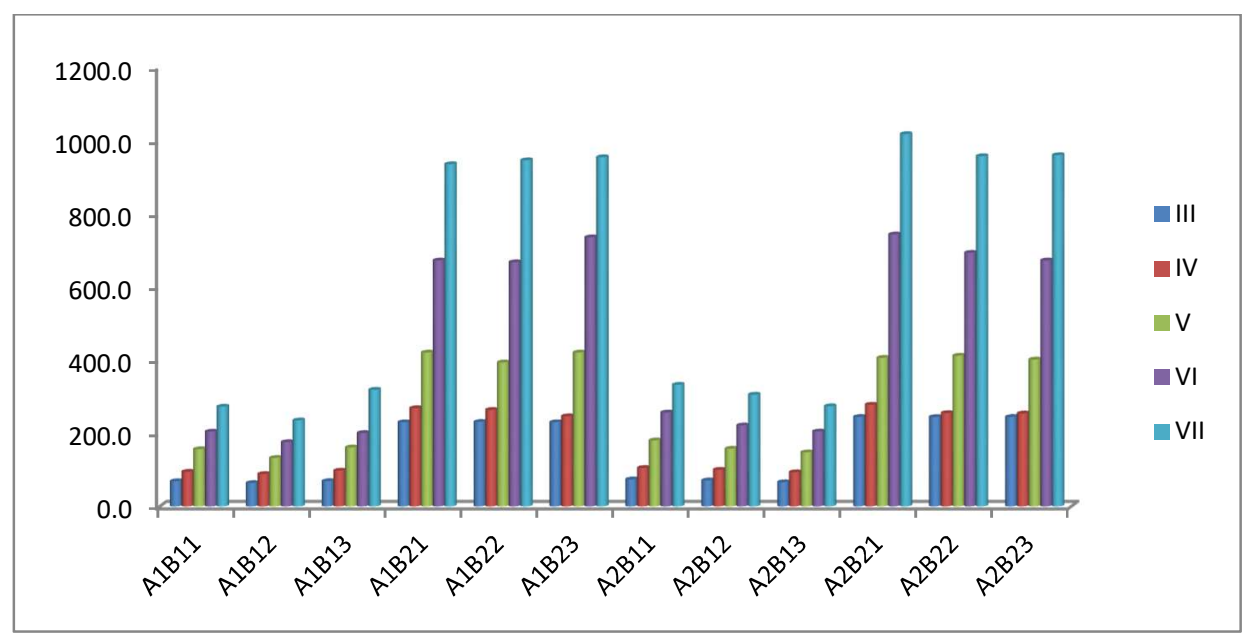

Figure 2. Total Weight Gain of Broilers and Native Chickens Fed Diet Containing Fermented and Unfermented Arenga Waste

\subsection{Consumption}

Chickens consume food first to meet their energy needs. Consumption influenced by many factors, besides protein content of feed. Arenga waste fermentation has no significant effect to feed consumption. The interaction between the type of chicken and the type of ration indicates that the effect is independent of each other. This indicates that the arenga waste has no palatability problem, just like the previous report [5]. There is not interaction between the types of chickens and the unfermented and fermented arenga waste. When considered weekly consumption, as expected by increasing the size of chicken, there was no dietary effect $(\mathrm{P}>0.05)$ on consumption. The interaction between the types of chickens and the types of rations does not show that the effect is independent of each other. The type of chicken shows there were significant differences $(\mathrm{P}<0.05)$, that the consumption of broiler chickens higher $(51,277$ grams/day) compared with native chicken (35.175 grams/day), and consumption of broiler chicken with arenga waste fermentation (43.370grams/day) than ration with unfermented arenga waste (43.082 gram/day). 
Feed consumption can be influenced by various factors, including nutrient content in the feed and the level of energy content in the ration [6]. The consumption of rations and the same broiler chickens will provide the same ration conversion, since the ration conversion is derived from the ratio of rations consumed within a certain time. The same consumption of rations followed by a uniform weight gain will result in no different ration conversions.

Table 3. Feed Consumption of Broilers and Native Chickens Fed Diet Containing Fermented and Unfermented Arenga Waste (grams/day)

\begin{tabular}{|c|c|c|c|c|}
\hline \multirow{2}{*}{$\begin{array}{c}\text { Factor A } \\
\text { (Arenga Waste) }\end{array}$} & \multicolumn{2}{|c|}{ Type of chicken } & \multirow[b]{2}{*}{ Average AB } & \multirow[b]{2}{*}{ Average A } \\
\hline & $\begin{array}{c}\text { B1 } \\
\text { (Native Chicken) }\end{array}$ & $\begin{array}{c}\text { B2 } \\
\text { (Broilers) }\end{array}$ & & \\
\hline A1 & 33.604 & 51.175 & 42.390 & \\
\hline (unfermented & 34.350 & 51.311 & 42.831 & \\
\hline arenga waste) & 37.031 & 51.022 & 44.026 & \\
\hline Average AB & 34.995 & 51.170 & & $43.082^{\mathrm{ns}}$ \\
\hline $\mathrm{A} 2$ & 36.814 & 51.385 & 44.100 & \\
\hline (Fermented arenga & 33.981 & 51.294 & 42.638 & \\
\hline waste) & 35.273 & 51.475 & 43.374 & \\
\hline Average $\mathrm{AB}$ & 35.356 & 51.385 & & $43.370^{\mathrm{ns}}$ \\
\hline Average B & $35.175^{\mathrm{a}}$ & $51.277^{\mathrm{b}}$ & & \\
\hline
\end{tabular}

Note: A1B1: Arenga waste unfermentation for chicken native; A1B2: arenga waste un fermentation for broiler chicken;

A2B1: Arenga waste fermentation for native chicken; A2B2: arenga waste fermentation for broiler chicken.

${ }^{a b}$ Means within the same row with different superscripts significantly different $(\mathrm{P}<0.05)$

\subsection{Feed Conversion}

The results showed that the conversion of native chicken was higher with ration of non-fermented arenga waste (5.173) than in chicken with ration of arenga waste fermentation $(5,643)$. The high rate of ration conversion shown in the study with the chicken indicated the ration used was not good. Conversion of rations reflects success in the selection or preparation of quality rations.

The ration conversion rate is influenced by three factors, namely the quality of the ration, the rationing technique and the mortality rate [7]. Conversion of rations is influenced by the temperature of the environment, the physical form of ration, the composition of rations and the substances contained in the ration [8].

High ration conversion values indicate the more rations needed to increase body weight per unit weight. The lower the conversion value indicates good quality rations [7]. Low conversion value is good and differs from beginning to end. In the final period after the age of four weeks, chicken growth becomes slow and begins to decline, while the use of rations continues to increase [9]. The conversion value of broiler chicken food when harvested now reaches a value below two [7]. Ration conversion is a benchmark for assessing how much feed is consumed into body tissue, expressed by the magnitude of body weight [10]. One of the variables used to see the ability of livestock to convert feed into meat-especially products is to look at the value of the resulting FCR. 
The lower the resulting FCR value indicates the value of feed consumption to increase the body weight (meat) lower [11].

Table 4. Feed Conversion of Broilers and Native Chickens Fed Diet Containing Fermented and Unfermented Arenga Waste

\begin{tabular}{lcccc}
\hline \multirow{2}{*}{$\begin{array}{c}\text { Factor A } \\
\text { (Arenga Waste) }\end{array}$} & \multicolumn{2}{c}{ Chickens of Type } & & \\
\cline { 2 - 3 } & $\begin{array}{c}\text { B1 } \\
\text { (Native Chicken) }\end{array}$ & $\begin{array}{c}\text { B2 } \\
\text { (Broilers) }\end{array}$ & & \\
\hline A1 & 5.753 & 2.540 & 4.147 & \\
(unfermented & 6.997 & 2.512 & 4.755 & \\
arenga waste) & 5.173 & 2.466 & 3.819 & \\
Average AB & 5.974 & 2.506 & & $4.24^{\mathrm{ns}}$ \\
A2 & 4.963 & 2.327 & 3.645 & \\
(Fermented arenga & 5.058 & 2.520 & 3.789 & \\
waste) & 5.915 & 2.519 & 4.217 & \\
Average AB & 5.312 & 2.456 & & $3.884^{\mathrm{ns}}$ \\
Average B & $5.643^{\mathrm{a}}$ & $2.481^{\mathrm{b}}$ & & \\
\hline
\end{tabular}

Note: A1B1: Arenga waste unfermentation for chicken native; A1B2: arenga waste un fermentation for broiler chicken;

A2B1: Arenga waste fermentation for native chicken; A2B2: arenga waste fermentation for broiler chicken.

${ }^{a b}$ Means within the same row with different superscripts significantly different $(\mathrm{P}<0.05)$

The results showed that arenga waste application of fermented and unfermented in a 7 week ration formulation not significantly different $(\mathrm{P}>0.05)$ on the mean of ration conversion. This shows that the use of arenga unfermented or fermented in broiler chicken and native chicken rations formulation during the study obtained the conversion value of feed is almost the same. The results of this study show that broiler chickens and chickens able to utilize the feed ingredients after fermented and formulated as needed. This suggests that rationing with locally formulated feeds containing fermented arenga waste can provide the level of palatability, quantity and balance of nutrients so effective in spurring growth and improving ration conversion. The smaller the conversion rate of feed, the more efficient the use of rations by livestock [12]. The value of feed conversion depends on the quality of feed given. The higher the nutrient conceived the better the conversion of the resulting feed. This happens because with a good feed the livestock need to consume less feed than the less good feed. Factors that influence the conversion of rations include the adequacy of food substances in the feed and the way of serving the feed on livestock [13]. 


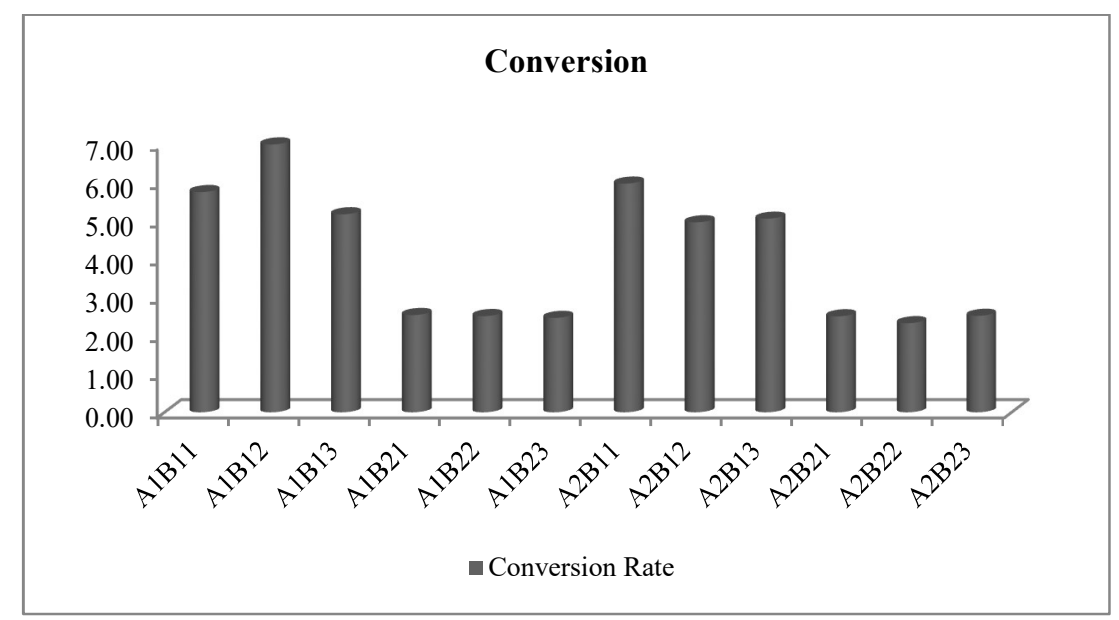

Figure 3. Feed Conversion of Broilers and Native Chickens Fed Diet Containing Fermented and Unfermented Arenga Waste

Although statistically not significantly different, the use of fermented and non-fermented arenga waste in broiler chicken and native chicken rations formulation tended to increase the rate of ration conversion. The high content of crude fiber limits the ability of the chicken to convert the rations consumed into body tissues. Growth rates and feed efficiency are influenced by the livestock's ability to consume, digest, absorb and metabolize nutrient feed [14]. The positive response of these effects is the improved feed efficiency seen by achieving low ration conversion value. The lower conversion value of the ration the livestock is more efficient in changing the feed into body tissue. Good growth reflects the efficiency of ration consumption seen from decreasing ration conversion rate [15].

\section{Conclusion and Recommendation}

Based on the research, it was concluded that the provision of fermented and unfermented arenga waste in broiler chicken and native chicken did not significantly effect the performance (body weight gain, consumption and conversion). Types of chicken (broiler chicken and native chicken) gives a very real effect on all parameters. There is no interaction between feeding with fermented arenga waste or unfermented with the type of chicken. It is recommended to provide arenga fermentation with Saccaromyses cereviceae for broilers and native chickens after 2 weeks.

\section{Acknowledgments}

On this occasion, we would like to thanks to the Directorate of Research and Community Service of the Directorate General for Research and Development of the Ministry of Research, Technology and Higher Education of the Republic of Indonesia and all those who assist in the implementation of this Research activity in 2018. 


\section{REFERENCES}

[1] U. Umiyasih and Y. N. Anggraeny, "Pengaruh Fermentasi Saccharomyces Cerevisiae Terhadap Kandungan Nutrisi dan Kecernaan Ampas Pati Aren (Arenga Pinnata Merr.)," presented at Seminar Nasional Teknologi Peternakan dan Veteriner, 2008.

[2] W. Utami, "Pengaruh Substitusi Tepung Jagung dengan Tepung Sagu Mutiara Afkir dalam ransum terhadap Performan Sapi PFH Jantan," Thesis, Universitas Sebelas Maret Surakarta, Surakarta, 2006.

[3] H. Tum and B. Wiro, "Pemanfaatan Ampas Sagu (Metroxylon Sagu) sebagai Pakan Ayam," presented at Seminar Nasional dan Veteriner, 1999.

[4] H. T. Uhi, S. Usman, Tirajoh and B. Tiro. Pengkajian pemanfaatan pakan ternak potensial di Irian Jaya. Laporan Hasil Pengkajian LPTP Koya Barat, Jayapura, 1997.

[5] A. G. Nataamijaya, T. Hermawati, H. Resnawati and A. Habibie, "Penggunaan Tepung Sagu Sebagai Bahan Ransum Anak Ayam Buras," Prosiding Seminar, 1988.

[6] T. Antawidjaja, I. A. K. Bintang, Supriyati, A.P. Sinurat, and I. P. Kompiang, "Penggunaan ampas kirai (Metroxylon sago) dan hasil fermentasinya," Jurnal Ilmu Ternak dan Veteriner, vol. 2, no. 3, pp. 175-180, 1997.

[7] H. P. Fan, M. Xie, W.W. Wang, S. S. Hou, and W. Huang. 2008. Effect of dietary energy on growth performance and carcass quality of white growing pekin ducks from two to six weeks of age," Poultry Science, vol. 87, no. 6, pp. 1162-1164, 2008.

[8] I. K. Amrullah, Nutrisi Ayam Broiler. Cetakan Ketiga. Bogor, Lembaga Satu Gunung Budi, 2004.

[9] National Research Council, Nutrient Requirement of Poultry. 9Th Revised Ed. Washington: National Academy Press, 1994.

[10] Rasyaf, Manajemen Peternakan Ayam Broiler. Jakarta: Penebar Swadaya, 2003.

[11] A. A. Ambara, I. N. Suparta, and I. M. Suasta, "Performan itik cili (persilangan itik peking $\mathrm{x}$ itik bali) umur 1-9 minggu yang diberi ransum komersial dan buatan dibandingkan itik bali," Peternakan Tropika, vol. 1, no. 1, pp. 20-33, 2013.

[12] A. D. Anggraini, F. Poernama, C. Hanim, and N. D. Dono, "Penggunaan protease dalam pakan yang menggunakan limbah pertanian-peternakan untuk meningkatkan kinerja pertumbuhan ayam broiler," Buletin Peternakan, vol. 41, no. 3, pp. 243-249, 2017.

[13] N. Arifah, Ismoyowati, and N. Iriyanti, "Tingkat pertumbuhan dan konversi pakan pada berbagai itik lokal jantan (Anas plathyrhinchos) dan itik manila jantan (Cairrina moschata). Jurnal Ilmiah Peternakan, vol. 1, no. 2, pp. 718 -725, 2013.

[14] B. Indarsih and M. H. Tamsil, "Feeding Diets Containing Different Forms of Duckweed on Productive Performance and Egg Quality of Ducks," Media Peternakan, vol. 35, no. 2, pp. 128-132, 2012.

[15] T. A. Scott, "Variation in feed intake of broiler chickens," Recent Advances in Animal Nutrition in Australia, vol. 15, 2005. 